\title{
Seasonal changes in the gonadossomatic index, allometric condition factor and sex ratio of an auchenipterid catfish from eastern Amazonia
}

\author{
Tiago Magalhães da Silva Freitas ${ }^{1}$, Vitor Hudson da Consolação Almeida ${ }^{2}$, Luciano \\ Fogaça de Assis Montag 2 , Rossineide Martins da Rocha ${ }^{3}$ and Nelson Ferreira Fontoura ${ }^{4}$
}

The aim of the present study was to evaluate the seasonal pattern of the gonadosomatic index (GSI), condition factor (K), and sex ratio in the catfish Auchenipterichthys longimanus (Siluriformes: Auchenipteridae) as an approach to identify its reproductive period. A total of 589 A. longimanus specimens (251 males and 338 females) were captured in the rivers of the Caxiuanã National Forest, in the Brazilian state of Pará, between July, 2008 and July, 2009. Among the male specimens, 171 were classified as adults and 80 as juveniles, while there were 249 adults and 89 juvenile females. Using a sinusoidal equation, analysis of the GSI revealed a reproductive asynchrony between the genders, with males attaining their highest GSI values in January, while females peaked in March. For males, the sinusoidal regression for GSI values was significant only when used the complete data set $(\mathrm{P}=0.001)$, wears no trend was identified for bimonthly means $(\mathrm{P}=0.136)$. For females, by contrast, significant values were obtained for both the complete data set $(\mathrm{P}=0.012)$ and bimonthly GSI means $(\mathrm{P}=0.026)$. For the condition factor, the sinusoidal equation returned significant seasonal variation in both raw data $(\mathrm{P}=0.02)$ and with mean values $(\mathrm{P}=0.00)$ for males, but only with raw data for females $(\mathrm{P}=0.04)$, which appears to reflect variation in the energy budget between genders. With regard to the sex ratio, more reproductive females were captured than males in January and March, 2009 , which suggests a pattern of segregation related to the reproductive process. These parameters are fundamental to the assessment, protection, and management of natural fish stocks, as well as providing guidelines for the development of conservation strategies.

O objetivo deste estudo foi avaliar alterações sazonais no índice gonadossomático (IGS\%), fator de condição (K) e proporção sexual, a fim de determinar o período de atividade reprodutiva do bagre Auchenipterichthys longimanus (Siluriformes: Auchenipteridae), a partir da análise de exemplares coletados em igarapés da Floresta Nacional de Caxiuanã, estado do Pará, Brasil. Através de coletas bimestrais entre julho de 2008 e julho de 2009, foram capturados 589 exemplares de A. longimanus, sendo 251 machos e 338 fêmeas. Dentre os machos, 171 exemplares foram classificados como adultos e 80 foram jovens, e dentre as fêmeas, 249 eram adultas e 89 jovens. Por meio do estabelecimento de uma equação senoidal, a análise do IGS\% evidenciou uma assincronia reprodutiva entre os sexos, pois os machos obtiveram maiores valores de IGS\% em janeiro e as fêmeas apresentaram seu pico em março. Para os valores de IGS\% de machos, a equação senoide mostrou-se significante somente para os valores brutos ( $\mathrm{P}=0,001)$, sendo não identificada uma tendência com os valores médios do IGS\% $(\mathrm{P}=0,136)$. Para as fêmeas, os valores de significância da equação senoide para o IGS\% foram obtidos tanto para os dados brutos $(\mathrm{P}=0,012)$ quanto para os dados médios $(\mathrm{P}=0,026)$. Para o Fator de Condição, a equação senoide demonstrou variação nos valores brutos e médios de machos adultos $(\mathrm{P}=0,02$ e $\mathrm{P}=0,00$, respectivamente) e nos valores brutos de fêmeas $(\mathrm{P}=0,04)$, refletindo diferenças nos padrões de investimento energético entre os sexos. Em relação à proporção sexual, foi observada uma maior frequência de capturas de fêmeas reprodutivas em relação aos machos nos meses de Janeiro e Março de 2009, sugerindo um padrão de segregação sexual com fins reprodutivos. Esses parâmetros são fundamentais na avaliação, conservação e manejo dos estoques naturais de peixes, assim como para subsidiar estratégias e procedimentos para a preservação e conservação da ictiofauna.

Key words: Auchenipterichthys longimanus, Hydrological seasons, Reproduction, Siluriformes.

\footnotetext{
${ }^{1}$ Universidade Federal do Pará (UFPA), Campus Universitário do Marajó, Faculdade de Ciências Naturais, Conjunto Bandeirante, Aeroporto,68800-000 Breves, PA, Brazil. freitastms@gmail.com

${ }^{2}$ Universidade Federal do Pará (UFPA), Laboratório de Ecologia e Zoologia dos Vertebrados, Instituto de Ciências Biológicas, Rua Augusto Corrêa, 01, Guamá, P. O. Box 479, 66.075-110 Belém, PA, Brazil. condevitor@yahoo.com.br (VHCA); montag@ufpa.br (LFAM)

${ }^{3}$ Universidade Federal do Pará (UFPA), Laboratório de Ultraestrutura Celular, Instituto de Ciências Biológicas, Rua Augusto Corrêa, 01, Guamá, P. O. Box 479, 66.075-110 Belém, PA, Brazil.rmrocha@ufpa.br

${ }^{4}$ Pontifícia Universidade Católica do Rio Grande do Sul (PUCRS), Faculdade de Biociências, Av. Ipiranga, 6681, P. O. Box 1429, 90619900 Porto Alegre, RS, Brazil.nfontoura@pucrs.br
} 


\section{Introduction}

The reproductive cycle of fish inhabiting rivers with inundated riparian areas (várzea or igapó) are strongly influenced by the seasonal flood dynamics. As recognize by many authors (e.g. Goulding, 1980), the floodplain provides feeding sites, nursery areas and protection from predators for many fish species. According to the flood pulse concept, proposed by Junk et al. (1989), the annual floodplain inundation triggers blooms of primary and secondary production, and the fish species in these complex systems have reproductive ecologies adapted to exploit this pulse of production (Bailly et al., 2008).

The understanding of these seasonal patterns provides an important baseline for the description of the fish biology and their role in aquatic ecosystems (Vazzoler, 1996). When direct inspection of gonadal maturation is not available, reproductive studies are frequently based on quantitative indices, as gonadosomatic index values (GSI) and condition factor (K), which help to define reproductive cycles and possible variation in the physiological condition of species during the course of its lifespan (Kreiner et al., 2001; Braga, 2005).

The analysis of gonadosomatic index values (GSI), which provide a measure of gonad size relative to body weight (Wootton, 1991), can provide a quantitative assessment of the degree of gonadal development, the breeding season, and the reproductive cycle (Gutiérrez-Estrada et al., 2000). The condition factor $(\mathrm{K})$ is another commonly-used index in the study of fish biology, which provides information on the physiological state of these animals, based on the assumption that individuals of a given body length are in better condition when their mass is greater (Jones et al., 1999; Anene, 2005). The condition factor depends on the coefficient of allometry (b) of the weight-length equation, which reflects the growth pattern of a species (Le Cren, 1951).

The inspection of the seasonal variation of the condition factor is also being used as a complementary parameter aiming to describe natural cycles in reproduction and feeding ecology (Braga, 1986; Lizama \& Ambrósio, 2000; Anene, 2005). However, the condition factor can suffer from any change related to the growth cycle of fish, a pattern already identified for perciforms (Bervian et al., 2006) and characiforms (Fontoura et al., 2010). Therefore, it would be appropriate to analyze such quantitative indices considering different size classes, since the energy budget of an individual can changes during ontogeny (Swain \& Foote, 1999).

Within teleost, several recent studies have demonstrated the important role played by seasonal floods on theses reproductive parameters both in temperate (Zeug \& Winemiller, 2007, 2008) and tropical rivers (Agostinho et al., 2004; Bailly et al., 2008). Nevertheless, the available studies on the biology and ecology of Auchenipteridae catfishes focus on few species (Araújo et al., 1999; Silva \& Viana, 2003; Bailly et al., 2008) and insufficient information are available for the driftwood catfish Auchenipterichthys longimanus (Günther, 1864).
Thus, the aim of the present study is to describe aspects of the reproductive cycle of the catfish A. longimanus by inspecting the seasonal cycles of gonadal maturity, variation in the gonadosomatic index, condition factor and sex ratio. Considering that fish species can modify the growth pattern during ontogeny, this paper aims also to evaluate changes in the condition factor concerning ontogenetic development.

\section{Material and Methods}

Samples were collected bimonthly between July, 2008 and July, 2009, in rivers located within the Caixuanã National Forest (145'27.5'S 51²7'33.2'W; Anapu River Basin), which are situated in the municipalities of Melgaço and Portel in the Brazilian state of Pará (Fig. 1). The sampling area is described as a blackwater river of a lowland amazon rainforest, being influenced both by the tide and by the seasonal oscillation of the Anapu River (Hida et al., 1999). However, both flows have very low amplitude and annual fluctuation do not exceed one meter as a general average (Hida et al., 1999). Typical flow cycle presents four hydrological periods (Fig. 2): drawdown (June-August), dry (September-November), filling (DecemberFebruary) and flood (March-May).

Specimens of $A$. longimanus were collected using $100 \mathrm{~m}$ long gillnets with a height of $1.5 \mathrm{~m}$, and meshes of $30 \mathrm{~mm}$ and $60 \mathrm{~mm}$. The nets were set for six hours per day at sites within the flooded forest sites selected with the guidance of a local fisherman. Following collection, the specimens were sexed, measured (total length in $\mathrm{cm}$ ), and weighed (body weight and gonad weight, in grams).

Also following collection, the stages of gonadal maturation were determined through macroscopic characteristics of the

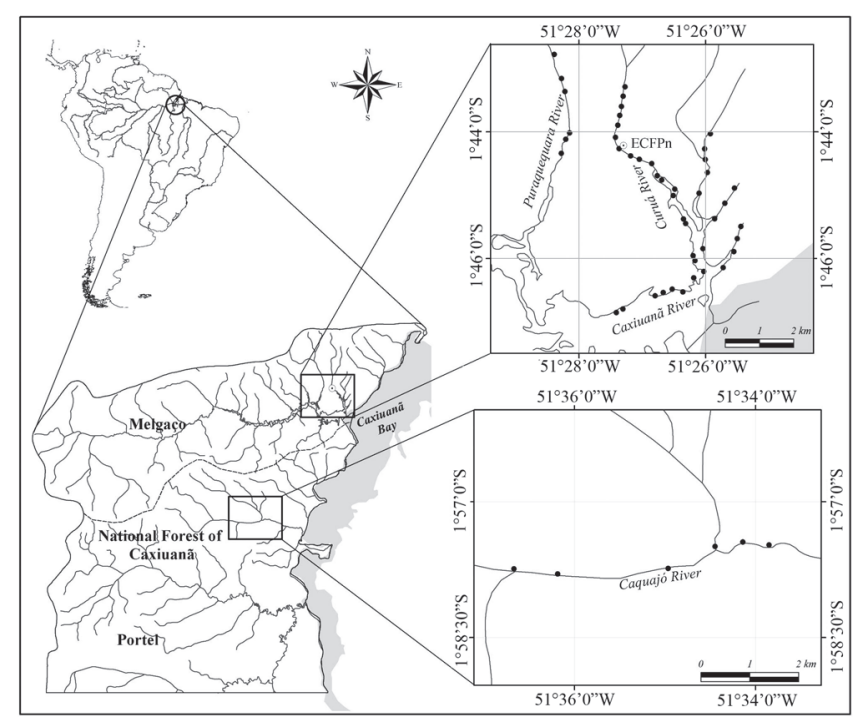

Fig. 1. Sampling area in the National Forest of Caxiuanã, Pará State, showing the rivers where the fish were collected. Curuá River - Ferreira Penna Research Station (ECFPn), Caxiuanã River; Puraquequara River and Caquajó River. Some black spots represent more than one collection site. 
gonads following the general description proposed by Vazzoler (1981): stage I (immature); gonads of reduced size, translucent, located adjacent to the vertebral column; stage II (maturing); gonads occupying a third of the abdominal cavity with well-developed capillary network; stage III (mature); gonads turgid, occupying the majority of the abdominal cavity (in the females, the oocytes are visible to the naked eye, while in the males, the testes are whitish); and stage IV (at rest or empty); gonad completely flaccid with a hemorrhagic aspect.

Then they were fixed in $10 \%$ formalin for approximately 48 hours before being conserved in $70 \%$ ethanol. The specimens were subsequently deposited in the ichthyological collection of the Museu Paraense Emílio Goeldi (MPEG) in Belém, Pará State, registered under the numbers MPEG 15257-15259, MPEG 15260-15264, MPEG 15432-15442, MPEG 15498-15507, MPEG 15544-15555, MPEG 15844-15860, and MPEG 16221-16231.

The breeding season was identified by using two different approaches: (1) the seasonal variation concerning relative frequencies of ovarian and testis classified according to the maturation stage; and (2) through the analysis of the seasonal variation in the gonadosomatic index (GSI) (Vazzoler, 1996; Becker et al., 2008; Carvalho et al., 2009; Santos et al., 2010).

The gonadosomatic index (GSI), defined as the percentage of the fish's total weight represented by the gonads (Vazzoler, 1996), was analyzed for each individual through the formula GSI $=\mathrm{Wg} / \mathrm{Wt} * 100$; where $\mathrm{Wg}$ is the weight of the gonads (g); and $\mathrm{W}_{\mathrm{t}}$ is the total weight of the individual $(\mathrm{g})$. Considering that only maturing/mature/spent individuals are related with reproductive events, the GSI analysis included only adult individuals. It was applied the Spearman correlation for the breeding parameter (GSI) and the regional flood pulse, aiming identify possible relationships between riverine water level and reproductive activity.

The allometric condition factor $(\mathrm{K})$ was analyzed for adults and juveniles separately, being estimated through the formula: $\mathrm{K}=\mathrm{Wt} / \mathrm{Lt} t^{\mathrm{b}}$; where $\mathrm{Lt}$ is the total length $(\mathrm{cm})$; and $\mathrm{b}$ is the coefficient of allometry of the weight-length relationship. Estimates of the size at first maturity and the allometric coefficients (b) for the weight/length relationship for $A$. longimanus follows Freitas (2010): males and females were considered adults with total lengths over 12.5 and $13.0 \mathrm{~cm}$ respectively; $\mathrm{b}$ values were 2.88 for juvenile males, 3.18 for adult males, 3.22 for juvenile females, and 2.95 for adult females.

For both parameters, GSI and the K, a sinusoidal equation (SE) was applied, following the approach of Fontoura \& Agostinho (1996) for the description of the seasonal effect of temperature on the growth of fish. The advantage of the use of time series instead of categorical ANOVA to compare reproductive parameters along the year is derived from the gain in terms of sensitivity due to the inclusion of additional information derived form a continuous process instead of independent categories. Also, regression models derived from sine functions allows the numerical description of the phenomena, and the direct comparison of time lags between distinct cycles. In this case, the sinusoidal function was

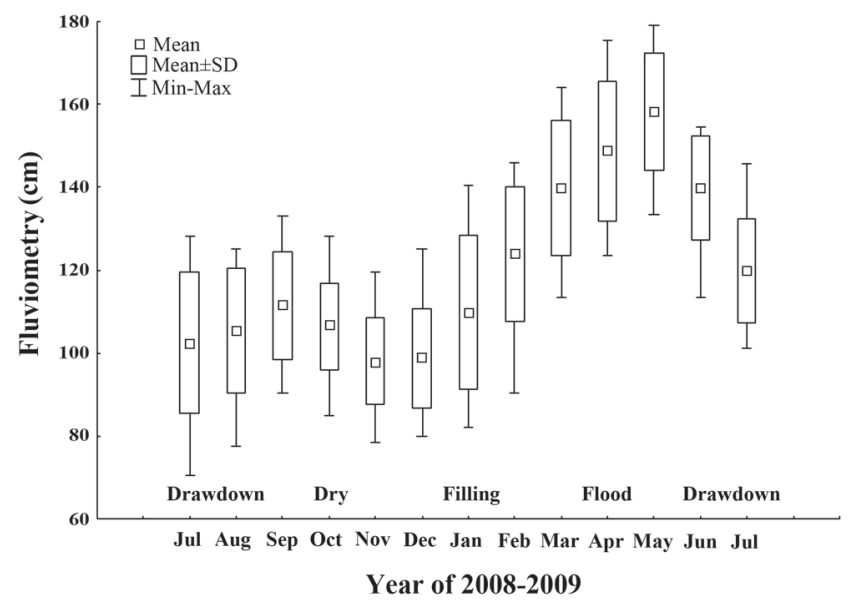

Fig. 2. Seasonal variation of the water level in the Caxiuanã National Forest. Data from the fluviometric station of Caiçara, Agência Nacional das Águas (ANA), from July 2008 to July 2009.

applied to the description of the annual variation of the indices (GSI and $\mathrm{K}$ ), using the formula:

GSI or $\mathrm{K}=\mathrm{M}+\mathrm{A} * \cos (2 \pi / \mathrm{Frq} *(\mathrm{t}-f))$,

where $\mathrm{M}$ is the mean annual GSI or $\mathrm{K}$; $\mathrm{A}$ is the amplitude of variation of GSI or K values; Frq is the unit of time in which the events were measured (here, Frq=12, considering that time is measured on a monthly scale); $\mathrm{t}$ is a numerical scale of time (i.e., January $=1$, February $=2$, March $=3$... December $=12$ ) and $f$ is the time difference between the baseline (zero) and the time with the maximum value of GSI or K. This latter parameter represents the month of the year with bigger estimated values for GSI or K.

The parameters of the sinusoidal function were estimated by using the Solver routine of the Microsoft Office Excel ${ }^{\mathbb{R}}$ 2007 (the Loss function using the least squares). The coefficient of determination $\left(\mathrm{R}^{2}\right)$ is calculated as the ratio between the residual sum of squares and total sum of squares (Zar, 1999). The $P$ values were obtained by the test of significance for the coefficient of determination, through the F statistic (Zar, 1999). Finally, the sex ratios recorded during the study were analyzed using the Chi-square test $\left(\chi^{2}\right)$, with a $5 \%$ significance level and null hypothesis of equal numbers of males and females through the study period.

\section{Results}

A total of 589 A. longimanus specimens were collected, of which 251 were males and 338 females. Of the males, 171 were classified as adults and 80 as juveniles, whereas the females consisted of 249 adults and 89 juveniles.

By analyzing the seasonal distribution of males and females in each maturation stages (Fig. 3), it was found fish in reproductive activity (stages II, III and IV) throughout the year. However, the more advanced reproductive stages (III and IV) suggest the mainly breeding during the flood period (March and May) for both genders, although the males 


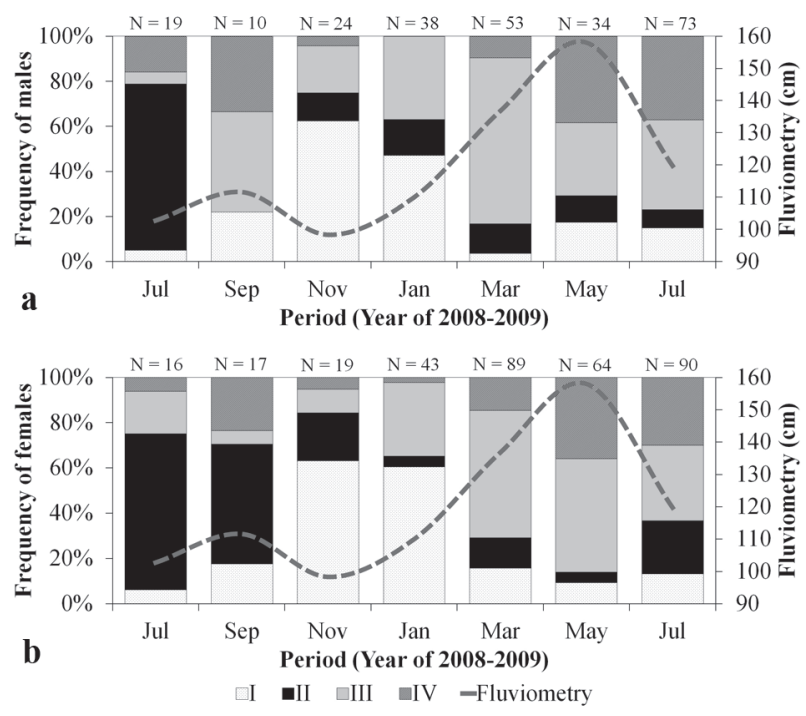

Fig. 3. Relative frequency (\%) of gonadal maturation stages of male (a) and female (b) of Auchenipterichthys longimanus collected from July 2008 to July 2009 in the Caxiuanã National Forest. Four gonadal maturation stages were identified: (I) Imature, (II) Maturing, (III) Mature and (IV) Spent. $\mathrm{N}=$ number of specimens analyzed. presented a high percentage of advanced reproductive stages also in September, during the dry season.

The mean GSI for adult males was $2.53(\mathrm{SD}=2.2 ; \mathrm{min}=0.03$; $\max =9.75$; mean stage $\mathrm{I}=0.20$, stage $\mathrm{II}=1.68$, stage $\mathrm{III}=4.05$, stage IV=1.38), and 2.72 for females $(\mathrm{SD}=2.91$; $\mathrm{min}=0.08$; $\max =18.76$, mean stage $\mathrm{I}=0.30$, stage $\mathrm{II}=0.99$, stage $\mathrm{III}=4.82$, stage IV=0.48). Differences between both genders in the monthly variation in the GSI are presented in Fig. 4, and the parameters used in the sinusoidal equation and their respective significance values are given in Table 1. Based on the sinusoidal equation adjusted for the gonadosomatic index (GSI), males presented the highest GSI values in January, $2009(f \approx 1$; filling period), while the females peaked in March, $2009(f \approx 3$; flood period). In the males, the sinusoidal regression was significant only for complete data set $(\mathrm{P}=0.001)$, wears no trend was identified for bimonthly means $(\mathrm{P}=0.136)$. In the females, by contrast, significant values were obtained for both the raw data $(\mathrm{P}=0.012)$ and the monthly means $(\mathrm{P}=0.026)$. The Spearman correlation also showed significance relationship between riverine water level and reproductive activity based on the GSI bimonthly variation ( $\mathrm{p}<0.05$ for both genders).

Seasonal variation in the condition factor $(\mathrm{K})$ is presented in Figs. 5 and 6 for males and females, respectively. Data concerning of the adjustment of the parameters of the sinusoidal
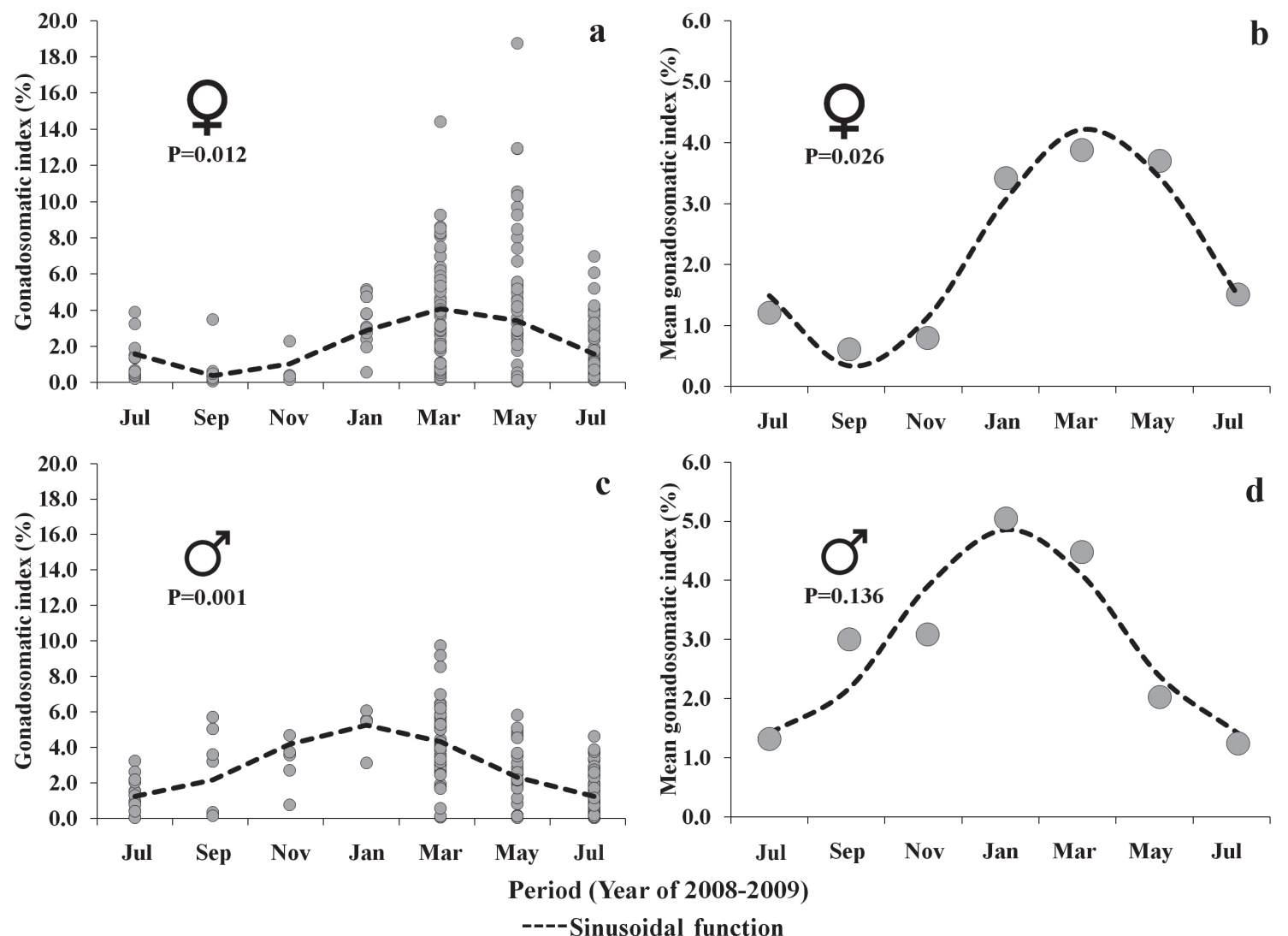

Fig. 4. Bimonthly variation in the raw data $(\mathbf{a}, \mathbf{c})$ and mean values $(\mathbf{b}, \mathbf{d})$ of the gonadosomatic index $(\mathrm{GSI})$ for female $(\mathbf{a}, \mathbf{b})$ and male (c, d) of the catfish Auchenipterichthys longimanus collected from July 2008 to July 2009 in the Caxiuanã National Forest. 
Table 1. Parameters of the sinusoidal equation for the variation of raw data and bimonthly means in the GSI of the catfish Auchenipterichthys longimanus collected from July 2008 to July 2009 in the Caxiuanã National Forest.

\begin{tabular}{|c|c|c|c|c|c|}
\hline \multirow{7}{*}{ 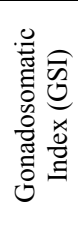 } & \multirow{2}{*}{ Parameters } & \multicolumn{2}{|c|}{ Males } & \multicolumn{2}{|c|}{ Females } \\
\hline & & Raw & Mean & Raw & Mean \\
\hline & Amplitude (A) & 2.010 & 1.726 & 1.872 & 1.948 \\
\hline & Mean (M) & 3.247 & 3.136 & 2.231 & 2.278 \\
\hline & Phase $(f)$ & 1.079 & 1.132 & 3.322 & 3.205 \\
\hline & $\mathrm{R}^{2}$ & 0.407 & 0.872 & 0.171 & 0.954 \\
\hline & $P$ value & 0.001 & 0.136 & 0.012 & 0.026 \\
\hline
\end{tabular}

equation and the significance values are presented in Table 2.

For the condition factor $(\mathrm{K})$, the sinusoidal equation for adult males was significant for both the raw data $(\mathrm{P}=0.027)$ and the mean values $(\mathrm{P}=0.000)$. For both equations, the "phase" parameter $(f)$ was approximately 7 , which represents month July (filling season). In juvenile males, variation in $\mathrm{K}$ was not significant during the study period for either the raw data $(\mathrm{P}=0.110)$ or the mean values $(\mathrm{P}=0.684)$.

In the adult females, variation in the sinusoidal equation for $\mathrm{K}$ was significant for the raw data $(\mathrm{P}=0.040)$, but not for mean values $(\mathrm{P}=0.586)$. Once again, the value of the phase $(f)$ for the raw data was close to 7 (July; filling season). As in the juvenile males, variation in $\mathrm{K}$ in juvenile females was not significant for either the raw data $(\mathrm{P}=0.086)$ or mean values $(\mathrm{P}=0.688)$.

For males the condition factor was highest in the juveniles $(\mathrm{K}=0.017 ; \mathrm{Kmin}=0.011 ; \mathrm{Kmax}=0.038)$ in comparison with the adults $(\mathrm{K}=0.009$; $\mathrm{Kmin}=0.006$; $\mathrm{Kmax}=0.014)$, due to the difference in the coefficient of allometry (b), which was 2.88 in the juveniles, and 3.18 in the adults. The situation is just the opposite in females, in which the highest $\mathrm{K}$ values were recorded for adults $(\mathrm{K}=0.018 ; \mathrm{Kmin}=0.010 ; \mathrm{Kmax}=0.026)$ in comparison with juveniles $(\mathrm{K}=0.008 ; \mathrm{Kmin}=0.005 ; \mathrm{Kmax}=0.014)$. As for males, these observed $\mathrm{K}$ values of females reflects also differences in the allometric coefficients for adult and juvenile ( $b=3.22$ for juveniles, and 2.95 for adults).

Considering the number of captured animals, there was an overall bias towards females $\left(\chi^{2}=12.85 ; \mathrm{P}=0.000\right.$; Table 3$)$, and the number of females exceeded that of males in March $(\mathrm{P}=0.003)$ and May $(\mathrm{P}=0.002)$, months of increased GSI values for females (Fig. 2a-2b).

\section{Discussion}

By analyzing both the frequency distributions of gonadal maturation stages and the seasonal variation of the GSI, we
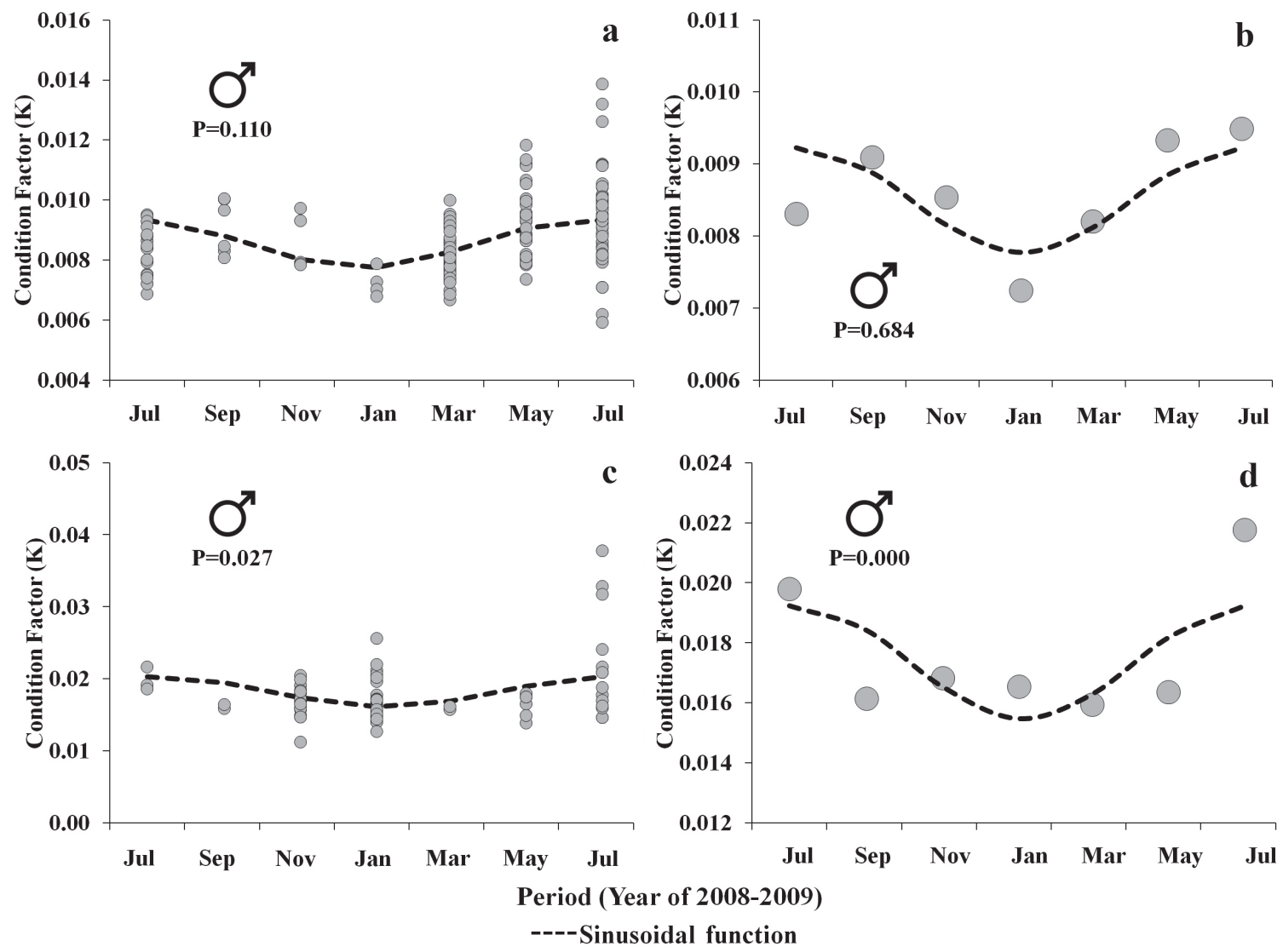

Fig. 5. Bimonthly variation in the raw data $(\mathbf{a}, \mathbf{c})$ and mean values $(\mathbf{b}, \mathbf{d})$ for the condition factor $(K)$ in juvenile $(\mathbf{a}, \mathbf{b})$ and adult (c, d) male of the Auchenipterichthys longimanus collected from July 2008 to July 2009 in the Caxiuanã National Forest. 


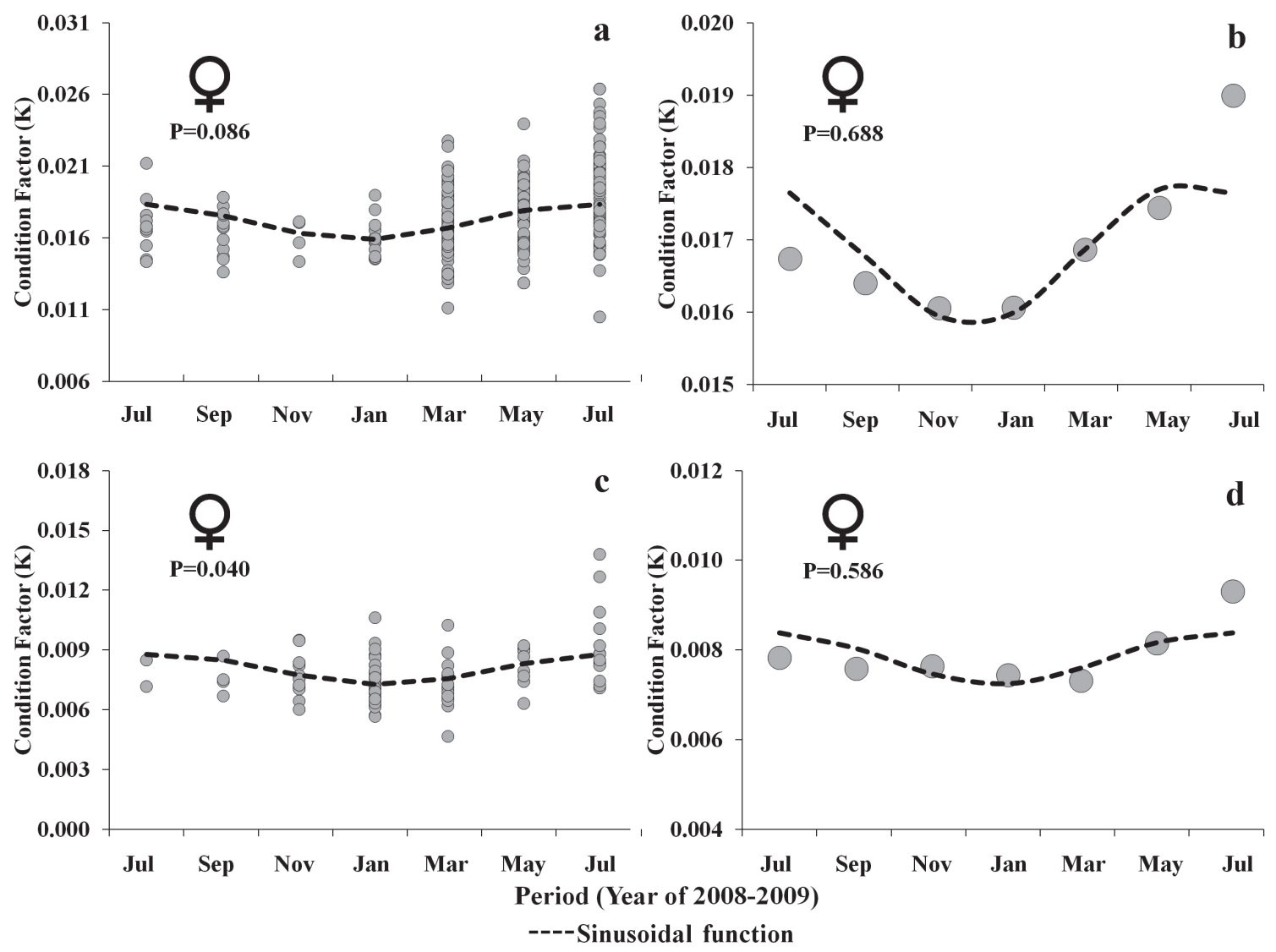

Fig. 6. Bimonthly variation in the raw data $(\mathbf{a}, \mathbf{c})$ and mean values $(\mathbf{b}, \mathbf{d})$ for the condition factor $(\mathrm{K})$ in juvenile $(\mathbf{a}, \mathbf{b})$ and adult (c, d) female of the Auchenipterichthys longimanus collected from July 2008 to July 2009 in the Caxiuanã National Forest.

suggest an extended spawning period for A. longimanus population in rivers of the Caxiuanã National Forest, a pattern similar to the already described for other auchenipterids (Araújo et al., 1999; Bailly et al., 2008). The reproductive period was identified with greater intensity during the flood period, in which the flooded forest forms a rich environment for fish (Goulding, 1980), suggesting the flood pulse as the primary environmental factor influencing fish recruitment (Zeug \& Winemiller, 2008).

In auchenipterids, Trachycorystes galeatus (=Trachelyopterus galeatus) presented the same pattern of asynchrony between males and females (Silva \& Viana, 2003). A similar condition was already recorded for other fish species as Piaractus mesopotamicus (Characiformes: Characidae) (Costa \& Mateus, 2009), Cathorops spixii (Siluriformes: Ariidae) (Fávaro et al., 2005) and a number of marine species (Murua \& Saborido-Rey, 2003).

Despite the observed asynchrony in the highest values of the gonadosomatic index (GSI) between genders - January for males and March for females - some females matured earlier than average. In this respect, it would be advantageous for a male to have early gonadal maturation, in order to be apt when the first females are ready for copulation, thus increasing their chances of success during a given breeding season (Fontoura et al., 2010).

Particularly for auchenipterid catfish, this asynchrony in GSI values may be reflecting the reproductive strategy of many species in this family. Burgess (1989) identified that the actual fertilization takes place only at the time of the egg deposition, without any males assistance, by using a storage of sperm (Melo et al., 2011), which the females could retain for up to four months (varying upon the species). Hence, the more accurate term "internal insemination" had been used recently instead "internal fertilization" (Burns et al., 2002; Mazzoldi et al., 2007; Parreira et al., 2009). This insemination strategy may also allow the temporal gap between mating and spawning (Pusey \& Stewart, 1989; Azevedo et al., 2000), as suggested for A. longimanus in this study (based on sex ratio; discussion below).

Concerning the condition factor, the difference in the allometric coefficient between juveniles and adults males $(b=3.22$ for juveniles, and 2.95 for adults) suggest a increased energy budget for adults males, probably related to the beginning of reproductive activities. Also, $\mathrm{K}$ values for males were highest in the period immediately before and after the month of spawning (January, 2009). In this month, a larger number of mature males with relatively smaller values of $\mathrm{K}$ were captured. In females, by contrast, the relationship 
Table 2. Parameters of the sinusoidal equation for the variation of raw and bimonthly means in the condition factor $(\mathrm{K})$ in Auchenipterichthys longimanus collected from July 2008 to July 2009 in the Caxiuanã National Forest.

\begin{tabular}{|c|c|c|c|c|c|c|c|c|c|}
\hline \multirow{8}{*}{ 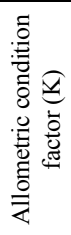 } & \multirow{3}{*}{ Parameters } & \multicolumn{4}{|c|}{ Male } & \multicolumn{4}{|c|}{ Female } \\
\hline & & \multicolumn{2}{|c|}{ Juvenile } & \multicolumn{2}{|c|}{ Adult } & \multicolumn{2}{|c|}{ Juvenile } & \multicolumn{2}{|c|}{ Adult } \\
\hline & & Raw & Mean & Raw & Mean & Raw & Mean & Raw & $\overline{\mathrm{Mea}}$ \\
\hline & Amplitude (A) & 0.002 & 0.002 & 0.001 & 0.001 & 0.001 & 0.001 & 0.001 & 0.00 \\
\hline & Mean (M) & 0.018 & 0.017 & 0.009 & 0.009 & 0.008 & 0.008 & 0.017 & 0.01 \\
\hline & Phase $(f)$ & 7.275 & 7.140 & 6.642 & 7.055 & 7.255 & 6.742 & 6.669 & 5.90 \\
\hline & $\mathrm{R}^{2}$ & 0.158 & 0.455 & 0.164 & 0.996 & 0.163 & 0.451 & 0.096 & 0.55 \\
\hline & $P$ value & 0.110 & 0.684 & 0.027 & 0.000 & 0.086 & 0.688 & 0.040 & 0.58 \\
\hline
\end{tabular}

between the breeding season and the condition factor was more discreet. Even so, it is possible to verify an inverse relationship between $\mathrm{K}$ and GSI, given that the highest mean value of $\mathrm{K}$ was recorded in July ( $\mathrm{K}=0.018$; phase $\approx 7$ ), when the females presented the lowest GSI values. These results also suggest that the reduction in $\mathrm{K}$ values reflects the energetic costs of the reproductive process for both males and females.

Although both the gonadosomatic index and the condition factor are applied for evaluation of the reproductive cycle in fish, values of K may also reflect any change in the feeding ecology of individual specimens (Braga, 1986; Kreiner et al., 2001; Gomiero $\&$ Braga, 2003; Anene, 2005). For both genders we observed that the changing pattern of the condition factor was inversely related to the GSI, which may be related to investments of the body's reserves into gonadal development (Braga, 1986) or energeticallydemanding reproductive strategies such as courtship and copulation (Peres \& Renesto, 2007).

Despite its relatively limited usefulness for the description of reproductive cycles in A. longimanus, the condition factor is relevant to inspect possible changes in the pattern of energy investment during individual life histories. For this reason, Goulart \& Verani (1992) suggested the use of the condition factor as an efficient indicator of seasonal variation in aspects of feeding ecology (e.g. diet change, energy absorption).

Silva \&Viana (2003) reported that Trachycorystes galeatus (= Trachelyopterus galeatus) presents a higher condition factor during the wet season in northeastern Brazil, when the water level spread over surrounding areas, providing a wider range of refuges and feeding sites. By contrast, Bailly et al. (2008) found that the gonadal development of three auchenipterid fishes (Auchenipterus osteomystax, A. nigripinis, and Parauchenipterus galeatus (= Trachelyopterus galeatus) were not affected by the hydrological cycle in the Brazilian Pantanal wetlands. These results emphasize that auchenipterid species can show different strategies in relation to the reproductive site and natural environmental cycle, and more studies on these species are in need to allow the understanding of the group framework.

With regard to the sex ratio, the present study recorded a predominance of females for A. longimanus. According to Nikolsky (1963) sex ratio deviations may be related to genetic
Table 3. Sex ratio for the catfish Auchenipterichthys longimanus collected in the Caxiuanã National Forest, Pará State, between July 2008 and July 2009.

\begin{tabular}{lcccccccc}
\hline \multirow{2}{*}{ Sex } & \multicolumn{4}{c}{2008} & \multicolumn{5}{c}{2009} \\
\cline { 2 - 9 } \multicolumn{1}{c}{} & Jul & Sep & Nov & Jan & Mar & May & Jul & Total \\
\hline Male & 19 & 9 & 24 & 38 & 54 & 34 & 73 & 251 \\
Female & 16 & 17 & 19 & 43 & 89 & 64 & 90 & 338 \\
Chi-square $\left(\chi^{2}\right)$ & 0.257 & 2.46 & 0.581 & 0.309 & 8.566 & 9.184 & 1.773 & 12.85 \\
P value & 0.612 & 0.117 & 0.446 & 0.579 & 0.003 & 0.002 & 0.183 & 0.000 \\
\hline
\end{tabular}

factors, differences regarding habitat occupation, differential mortality rates, and even biased sampling by the fishing equipment (Barbieri, 1992; Hojo et al., 2004). A change in the sex ratio may happen not only among populations of a given species, but also within the same population during different periods (Nikolsky, 1963). In the present study, the predominance of females was especially marked during the spawning period (January through March, 2009), which suggests a pattern of sexual segregation during the reproductive process.

Concluding, the present study concerning aspects of the reproductive biology of $A$. longimanus in the blackriver system of the Caxiuanã National Forest identified an extended spawning period, but with increased reproductive activity related to the flooding cycle. Differences in the condition factor $(\mathrm{K})$ were also recorded, which could be reflecting variation in the energy budget between genders and size classes related to the attainment of maturity. An identified asynchrony between males and females in the reproductive process may be related to the species' internal fertilization strategy, with females retaining sperm prior to spending.

\section{Acknowledgements}

The authors are grateful to the Fundação Grupo O Boticário de Proteção à Natureza, the Program in Biodiversity Research (PPBio/Caxiuanã), and CNPq for financial support. We also thank CAPES, for support through the Programa Nacional de Cooperação Acadêmica - Novas Fronteiras (PROCAD-NF), Mr. Benedito Brazão for his assistance in the field and to Dr. Stephen F. Ferrari for his assistance with the english review.

\section{Literature Cited}

Agostinho, A. A., L. C. Gomes, S. Veríssimo \& E. K. Okada. 2004. Flood regime and fish: effects on spawning, recruitment and attributes of the assemblages in the upper Paraná River floodplain. Reviews in Fish Biology and Fisheries, 14: 11-19.

Anene, A. 2005. Condition Factor of Four Cichlid Species of a Man-made Lake in Imo State, Southeastern Nigeria. Turkish Journal of Fisheries and Aquatic Sciences, 5: 43-47.

Araújo, F. G., S. Duarte, R. S. Goldberg \& I. Fichberg. 1999. Indicadores reprodutivos de Parauchenipterus striatulus (Steindachner) (Pisces, Auchenipteridae) na Represa de Ribeirão das Lajes, Rio de Janeiro, Brasil. Revista Brasileira de Zoologia, 16: 1071-1079. 
Azevedo, M. A., L. R. Malabarba \& C. B. Fialho. 2000. Reproductive biology of the inseminating glandulocaudine Diapoma speculiferum Cope (Teleostei: Characidae). Copeia, 2000: 983-989.

Bailly, D., A. A. Agostinho \& H. I. Suzuki. 2008. Influence of the flood regime on the reproduction of fish species with different reproductive strategies in the Cuiabá River, Upper Pantanal, Brazil. River Research and Applications, 24: 1218-1229.

Barbieri, G. 1992. Biologia de Astyanax scabripinnis paranae (Characiformes, Characidae) do Ribeirão do Fazzari, São Carlos, São Paulo. Revista Brasileira de Biologia, 52: 589-596.

Becker, F. G., S. Carvalho \& S. M. Hartz. 2008. Life-history of the South American darter, Characidium pterostictum (Crenuchidae): evidence for small scale spatial variation in a piedmont stream. Neotropical Ichthyology, 6: 591-598.

Bervian, G., N. F. Fontoura \& M. Haimovici. 2006. Statistical model of variable allometric growth: otolith growth in Micropogonias furnieri (Actinopterygii, Sciaenidae). Journal of Fish Biology, 68: 196-208.

Braga, F. M. S. 1986. Estudo entre fator de condição e relação pesocomprimento para alguns peixes marinhos. Revista Brasileira de Biologia, 46: 339-346.

Braga, F. M. S. 2005. Feeding and condition factor of characidinn fish in Ribeirão Grande system, Southeastern Brazil. Acta Scientiarum Biological Sciences, 27: 271-276.

Burgess, W. E. 1989. An Atlas of Freshwater and Marine Catfishes: a preliminary survey of the Siluriformes. New Jersey, T. F. H. Publication, 784p.

Burns, J. R., A. D. Meisner, S. H. Weitzman \& L. R. Malabarba. 2002. Sperm and Spermatozeugma Ultrastructure in the Inseminating Catfish, Trachelyopterus lucenai (Ostariophysi: Siluriformes: Auchenipteridae). Copeia, 2002: 173-179.

Carvalho, P. A., A. L. Paschoalini, G. B. Santos, E. Rizzo \& N. Bazzoli. 2009. Reproductive biology of Astyanax fasciatus (Pisces: Characiformes) in a reservoir in southeastern Brazil. Journal of Applied Ichthyology, 25: 306-313.

Costa, R. M. R. \& L. A. F. Mateus. 2009. Reproductive biology of pacu Piaractus mesopotamicus (Holmberg, 1887) (Teleostei: Characidae) in the Cuiabá River Basin, Mato Grosso, Brazil. Neotropical Ichthyology, 7: 447-458.

Fávaro, L. F., F. A. Frehse, R. N. Oliveira \& R. Schwarz-Jr. 2005. Reprodução do bagre amarelo, Cathorops spixii (Agassiz) (Siluriformes, Ariidae), da Baía de Pinheiros, região estuarina do litoral do Paraná, Brasil. Revista Brasileira de Zoologia, 22: 1022-1029.

Fontoura, N. F. \& A. A. Agostinho. 1996. Growth with seasonally varying temperatures: an expansion of the von Bertalanfy growth model. Journal of Fish Biology, 48: 569-584.

Fontoura, N. F., A. S. Jesus, G. G. Larre \& J. R. Porto. 2010. Can weight/length relationship predict size at first maturity? A case study with two species of Characidae. Neotropical Ichthyology, 8: 835-840.

Freitas, T. M. S. 2010. Aspectos ecológicos do cachorro-de-padre Auchenipterichthys longimanus (Siluriformes: Auchenipteridae) em igarapés da Amazônia Oriental, Pará, Brasil. Unpublished Master Dissertation, Universidade Federal do Pará/Museu Paraense Emílio Goeldi, 106p.

Gomiero, L. M. \& F. M. S. Braga. 2003. Relação peso-comprimento e fator de condição para Cichla cf. ocellaris e Cichla monoculus (Perciformes, Cichlidae) no reservatório de Volta Grande, rio Grande - MG/SP. Acta Scientiarum Biological Sciences, 25: 79-86.

Goulart, E. \& J. R. Verani. 1992. Proporção sexual, relação peso/ comprimento e fator de condição de Hypostomus commersonii
Valenciennes, 1840 (Osteichthyes, Loricariidae) da represa Capivari-Cachoeira, Paraná, Brasil. Revista Unimar, 14: 19-33.

Goulding, M. 1980. The fishes and the forest. Explorations in Amazonian natural history. California, University of California Press, 280p.

Gutiérrez-Estrada, J. C., I. Pulido-Calvo \& J. Prenda. 2000. Gonadosomatic index estimates of an introduced pumpkinseed (Lepomis gibbosus) population in a Mediterranean stream, using computational neural networks. Aquatic Sciences, 62: 350-363.

Hida, N., J. G. Maia, M. Hiraoka, O. Shimm \& M. Nobuaki. 1999. River water level changes of the Amazon Estuary: at Breves, Caxiuanã and Abaetetuba. Manaus'99 - Hydrological and Geochemical Processess in Large Scale River Basins, p.1-9.

Hojo, R. E. S., G. B. Santos \& N. Bazzoli. 2004. Reproductive biology of Moenkhausia intermedia (Eigenmann) (Pisces, Characiformes) in Itumbiara Reservoir, Goias, Brazil. Revista Brasileira de Zoologia, 21: 519-524.

Jones, R. E., R. J. Petrell \& D. Pauly. 1999. Using modified lengtweight relationships to assess the condition of fish. Aquacultural Engineering, 20: 261-276.

Junk W. J., P. B. Bayley \& R. E. Sparks. 1989. The flood pulse concept in river-floodplain systems. Canadian Special Publication of Fisheries and Aquatic Science, 106: 110-127.

Kreiner, A., C. D. Van der Lingen \& P. Fréon. 2001. A comparison of condition factor and gonadosomatic index of sardine Sardinops sagax stocks in the Northern and Southern Benguela upwelling ecosystems, 1984-1999. African Journal of Marine Science, 23: 23-34.

Lassala, M. D. P. \& E. Renesto. 2007. Reproductive strategies and genetic variability in tropical freshwater fish. Genetics and Molecular Biology, 30: 690-697.

Le Cren, E. D. 1951. The length - weight relationship and seasonal cycle in gonad weight and condition in the perch (Perca fluviatilis). Journal of Animal Ecology, 20: 201-219.

Lizama, M. de los A. P. \& A. M. Ambrósio. 2000. Condition factor in nine species of fish of the Characidae family in the upper Paraná River floodplain, Brazil. Brazilian Journal of Biology, 62: 113-124.

Loir, M., C. Cauty, P. Planquette \& P. Y. Le Bail. 1989. Comparative study of the male reproductive tract in seven farnilies of SouthAmerican catfishes. Aquatic Living Resources, 2: 45-56.

Mazzoldi, C., V. Lorenzi \& M. B. Rasotto. 2007. Variation of male reproductive apparatus in relation to fertilization modalities in the catfish families Auchenipteridae and Callichthyidae (Teleostei: Siluriformes). Journal of Fish Biology, 70: 243-256.

Melo, R. M. C., F. P. Arantes, Y. Sato, J. E. Santos, E. Rizzo \& N. Bazzoli. 2011. Comparative Morphology of the Gonadal Structure Related to Reproductive Strategies in Six Species of Neotropical Catfishes (Teleostei: Siluriformes). Journal of Morphology, 272: 525-535.

Murua, H. \& F. Saborido-Rey. 2003. Female reproductive strategies of marine fish species of the North Atlantic. Journal of Northwest Atlantic Fishery Science, 33: 23-31.

Nikolsky, G. V. 1963. The ecology of fishes. Nova York, Academic press, 352p.

Parreira, G. G., H. Chiarini-Garcia, R. C. N. Melo, F. O. Vieira \& H. P. Godinho. 2009. Spermatozoon and Its Relationship with the Ovarian Lamellae in the Internally Inseminating Catfish Trachelyopterus galeatus. Microscopy Research and Technique, 72: 889-897.

Pusey, B. J. \& T. Stewart. 1989. Internal fertilization in Lepidogalaxias salamandroides Mees (Pisces: Lepidogalaxiidae). Zoological Journal of the Linnean Society, 97: 69-79. 
Santos, N. B., R. M. Rocha \& F. L. Fredóu. 2010. Reproductive biology of Plagioscion magdalenae (Teleostei: Sciaenidae) (Steindachner, 1878) in the bay of Marajo, Amazon Estuary, Brazil. Neotropical Ichthyology, 8: 333-340.

Silva, A. C. \& M. S. R. Viana. 2003. Época de desova do cangati, Trachycorystes galeatus (Linnaeus, 1756), no Açude Pereira de Miranda (Pentecoste-Ceará-Brasil). Revista Ciência Agronômica, 34: 5-10.

Swain, D. P. \& C. J. Foote. 1999. Stocks and chameleons: the use of phenotypic variation in stock identification. Fisheries Research, 43: 113-128.

Vazzoler, A. E. A. M. 1981. Manual de métodos para estudos biológicos de populações de peixes: Reprodução e crescimento. CNPq, Programa Nacional de Zoologia, Brasília, 106p.

Vazzoler, A. E. A. M. 1996. Biologia da reprodução de peixes teleósteos: teoria e pratica. Maringá, EDUEM, 169p.

Wootton, R. J. 1991. Ecology of teleost fishes. London, Chapman and Hall, 404p.

Zar, J. H. 1999. Biostatistical Analysis ( $4^{\text {th }}$ d. $)$. New Jersey, Prentice-Hall, 663p.

Zeug, S. C. \& K. O. Winemiller. 2007. Ecological correlates of fish reproductive activity in floodplain rivers: a life history-based approach. Canadian Journal of Fisheries and Aquatic Sciences, 64: 1291-1301.

Zeug, S. C. \& K. O. Winemiller. 2008. Relationships between hydrology, spatial heterogeneity, and fish recruitment dynamics in a temperate floodplain river. River Research and Applications, 24: 90-102.

Submitted October 1, 2010

Resumitted June 30, 2011

Accepted September 26, 2011

Published December 26, 2011 